\title{
The counter argument against environmental reductionism in Latinx immigration debates: Tracking the discussion and empirical evidence ${ }^{1}$
}

\author{
Carolina Velandia Hernández ${ }^{\dagger 2}$ Northern Illinois University
}

This article discusses the debate and empirical bases of the environmental argument against Latinx immigration to the United State (US) since the 1980s decade. The environmental argument against immigration states that the level of immigration (undocumented and legal) has a statistical impact on the $\mathrm{CO} 2$ emissions, quality of air, and pollution. The argument also declares that immigrants exceed the emissions if they remained in their country of origin since the 1980s decade, and that immigration rapidly consumes environmental resources such as water, air, land, and increases biodiversity loss. This argument has neo-Malthusian, social Darwinism, and racist biases. This paper presents the core debates around the primary premises, the evolution inside the environmental movement in the US. This paper argues that the environmental argument against Latinx immigration lacks generalizable studies, objective data, and scientific validity. The environmental argument evolution has not present enough academic to support to its main claim that connects immigration with environmental degradation. Instead, we argue that immigration it is not the only cause of population growth, the environmental argument denies the strong evidence and studies that linkage environmental degradation with industrialization levels, emissions, economic development, and consumption levels of the US citizens.

Keywords: environmental argument, immigration, empirical support, population growth.

\footnotetext{
${ }^{1}$ Preliminary Draft. Please do not cite or circulate without author's permission.
}

2 PhD student in the Political Science and Public Administration department. 


\section{Introduction}

Think tanks and authors have used and promoted an environmental argument against Latinx immigration since the 1970s. The argument is that the level of immigration (undocumented and legal) has a statistical impact on the $\mathrm{CO} 2$ emissions, quality of air, and pollution. The idea is that the emissions produced by immigrants exceed the emissions they would likely have produced if they remained in their country of origin. They argue that emissions from immigrants tend to increase since the 1980s decade (Kolankiewicz \& Camarota, 2008). The same thought supports the idea that immigration rapidly consumes environmental resources such as water, air, land, and increases biodiversity loss. The environmental argument against immigration downplays the role of corporations, US citizens' consumerism, or public policies' effects. The argument is attached to a revision of the Malthusian thesis that the population growth is the causal explanation in the increase of any environmental degradation, in this case, $\mathrm{CO} 2$ emissions. It is also a remake of social Darwinism and to a large nativist restictionist ideology inside of the environmentalist thinking groups that have a primary goal to reduce immigration flows (Beltran, 2020; Hultgren, 2012, 2014). This paper will present the evolution of the environmental argument against immigration, the reactions of the literature, and provide empirical evidence against it. This paper argues that the environmental argument against Latinx immigration is a continuation of race biases ideology that looks eager for theoretical and empirical evidence to provide foundation on an argument that is ethically, and politically incorrect. The paper is divided as follows: first, the presentation of the environmental argument, followed by the debate and the empirical evidence already founded by the literature against the environmental argument, and finally, the conclusion as an evaluation of the strength of the environmental argument.

\section{The environmental argument}

The environment argument is also known as the environmental restictionist. It states that the level of immigration (undocumented and legal) has a statistical and evident impact on the environmental degradation, especially on $\mathrm{CO} 2$ emissions, quality of air, and pollution. The main premises of the argument are immigration rapidly consumes environmental resources such as water, air, land, and increase biodiversity loss. In addition, population growth is the causal explanation of the increase of emissions and other forms of contamination.

Relevant works that support the environmental restrictionist argument on limiting immigration flows are: (1) The work of Kolankiewicz and Camarota (2008) which correlates annual income with annual emission of $\mathrm{CO} 2$ from fossil fuel consumption. They estimate that "637 million 
tons of $\mathrm{CO} 2$ emissions generated by immigrants is roughly equal to the annual $\mathrm{CO} 2$ emissions of Brazil, Argentina, and Venezuela". According, to their finding, immigrants produce less than the average native-born American, but by immigrating to the US, their emissions increase four times in comparison with those they would have done in their countries of origin. They believe that population growth plays a key role in climate change and emissions.

(2) In the work of Cafaro and Staples III (2009), they argue that creating a sustainable society requires a more restrictive immigration policy. The historical immigration levels are the principal driver of population growth and its contribution to environmental damages increases urban sprawl. Consumption and energy sources are not the problem. The policy tool to address this problem being committed with environmentalism is to reduce immigration. Their policy proposal includes reducing immigration, persecuting undocumented immigrants, punishing employers that profit from undocumented labor, and renegotiating for Free Trade Agreements to allow recovery of the domestic economies of the immigrants' countries of origin.

The environmental argument against immigration considers population growth strongly attached to land use. It raises the question about who has the right to use the resources of the land and creates a cause-and-effect relationship. Which states that if population grows due to immigration flows, the immigrants will be regarded as the cause of the environmental destruction. For instance, Beck et. al. (2003) argument stated that land use and population growth can only be addressed by reducing immigration.

The new immigration increases birthrates, population, and urban sprawl which in turn, threatens rural land. Therefore, to intensify smart growth programs should address the rapid population growth, land use, zoning, and legal challenges. The authors suggest that urban sprawl must be reduced by recognizing that rapid population growth is the cause rather than the ethnic characteristics of the immigrants.

To summarize, the environmental argument can be more or less strict on creating the causal relationship of population growth with environmental degradation. However, the debate has ideological origins and the role of the principal thinkers' groups in the US environmental movement, created a scenario in the last decades where these ideas were debated and refuted. This will be addressed in the next subsection.

\section{The debate}

The debate in the US can be addressed in two layers, the evolution inside of the American environmentalism, and the scientist debate on population growth impact on climate change and environmental degradation arguments. 
In the early 2000s, the work of Beck and Kolankiewicz (2000) claimed that the American environmental movement changed, thus, abandoning the argument of population stabilization as a goal for the movement. They explained that this change occurred in the 1970s. Beck and Kolankiewicz argued that pro-immigration advocates and corporations that support lower skill workers supply, push for these changes inside the most relevant environmental groups in US, the Zero Population Growth (ZPG), and the Sierra Club. They also argued that from the 1970s to the 1990s, concepts such as environmental justice and globalization came into place. The purpose was to signify the global differences in economic development and its implications in sustainability, employment, and race discrimination in US, creating changes in the environmentalist speech. However, they believe that the transformation of population and environment in global issues requires a recognition that the population policy is the main factor.

King (2008) argues that the ideological and strategic choices of the environmentalist movement are associated with the conflicts inside of the organization of social movements. In the case of Sierra Club activist, the disagreement was over the strategy rather than the ideology. Apparently, most of the authors and thinkers agreed on the population stabilization policies and its linkage with environmental/social justice. The Sierra Club disputes did not lead to a big organizational transformation or a strong statement against immigration. The funding and resources where not the key element that led to the divergence views over immigration and environment, rather, it was an ideological debate concerned with the relationship between population growth, immigration, and environment. The pragmatic reason that led to a no opposition of immigration US policy changes in the Sierra Club is also attached to the variance on the number of immigrants entering the US and the public opinion change over time.

Another explanation comes from the work of Hultgren (2012) which argues that the origin of the debate inside American environmentalism focused on the immigration problem is the debate of Robyn Ekersley and Mick Smith. The core of the debate is over the Green State versus ecological sovereignty. Ekersley (2006) argues that sovereignty with a green state confront the ecologically destructive neoliberalism which gives privilege to corporations and non-states actors, allowing them environmental impacts. For Eckersley, national solidarity is a precondition of ecological democracy, there emerges the need to exclude others. A Green State excludes those that are not citizens. On the contrary, Smith (2011) argues that Ecological Sovereignty allows states to take arbitrary decision under a green nation-state. The Sovereignty concept is malleable and allows state to act in crisis periods suspending the normal political order. Therefore, an eco-sovereign state regulates biopolitical structure, creating states of exception that push for impulses negate any radical 
shift in environmental governance. Hulgreen (2012) explains the division of the environmentalist movement and thinking in the US. Into those that combined a Malthusian political economy for population growth with Darwinian natural science applied to society. Which creates narratives of exception where the conclusion is to marginalize and exclude others (those that do not belong to the nation).

This is why the environment argument is also recognized as the environmental

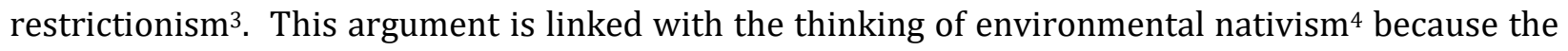
use of sovereignty that utilizes scientific concepts to construct the concept of nation build up smoothly on racialized projects where the source of pollution are nonwhite populations (speech of the other and white democracy as precondition for legitimacy) (Kendall, 2016; Wood, 2009; Nevins, 2002). The opposite argument considers the biopolitical counter argument, which evaluates the pathway of the state of exception. It includes environmental justice, impacts of globalization in the Global South, and other large causes as industrialization, consumerism, and market policies as the main causes of environmental degradation. The consideration of subaltern identities adjusts hegemonic nationalism in a more inclusive way, and explain that states of exception can impact already marginalized populations (Hultgren, 2012. 305).

The scientific debate has a different focus on the argument based on the Anthropocene, concept that considers the impact of human activity on the environmental degradation, land use, and principal causes of climate change and environmental impacts such as the use of energy sources based on the geological force of human action. For example, the group of scientists that considers there is a correlation among human population size, growth, density, and overconsumption with the impacts on the environment, pollution sources and especially on biodiversity conservation. Their explanation considers that population density and size are linked with the reduction of areas under protection, the increase of carbon emissions, and those effects on the environment lead to animal species to decline (McKee et al. 2013; Rust \& Kehoe, 2017). However, this group of scientists do not suggest that immigration flaws alone is the cause of this environmental effect, they suggest instead that human population size as a whole and its connections with industrial and urban activity are

\footnotetext{
3 One quote from the Hulgrean work quoting King's (2008) studyt illustrate the divisions inside of the environmental movement in the US: "Although major environmental organizations in the United States remain "neutral" on the issue of immigration, internal debates have been incredibly divisive, ${ }^{49}$ and numerous well-known environmental advocates (including Garrett Hardin, Edward Abbey, Paul Ehrlich, Gaylord Nelson, Herman Daly, David Brower, George Sessions, William Rees, "Captain" Paul Watson, and Lester Brown) have voiced support for the restrictionist cause. Struggles within the Sierra Club, in particular, have brought the issue into the national spotlight, and although the organization has been mostly successful in fending off restrictionist efforts, there remains significant sympathy for immigration reduction proposals among the membership. ${ }^{50}$ "(P. 307)

${ }^{4}$ Mudde's (2017) nativist definition is a xenophobic form of nationalism, that observes nonnative persons and their ideas a threat for the nation -state's culture, security an economic well being.
} 
more determinant. For example, those studies also consider dynamics of female education in the rates of population growth and suggest there is a need to be studied more in diverse societies to find solutions to this effects and that there is probabilistic methods that suggest human population growth will not exceed 10 billion before 2100 (Lutz et al. 2001).

The scientific discussion specifically addresses climate change. When considering what are the real actions that can be done immediately for reducing pollution or emissions, the scientist does not recommend stopping immigration flows. They argue that to reduce global warming pollution strategies currently available to reduce the carbon emission are: a change in the economy wide making a reduction in carbon intensity, which means efficient vehicles, buildings, and baseload coal plants, reduce use of vehicles, use of renewable or alternative sources as hydrogen, biofuels, wind electricity. Similarly, management of tropical forest and agricultural soils can avoid deforestation and erosion. (Lashof \&Hawkins, 2006; Pacala \& Socolow, 2004)

The two layers of debate show that the environmental movement does not consider in the linkage population growth and environmental/social justice actual opinions and literature of scientific specialist that argue that the main causes of environmental degradation are levels of industrialization, consumerism, and the Global North' way of life.

\section{Arguments against and some empirical evidence}

The following studies had already produced empirical evidence over the flaws of the environmental argument against migration. Ma and Hoffmann (2018) provide empirical evidence of the limitation of the association between immigration and air quality. By using the environmental protection Agency's Environmental Quality Index (EQI) they examine the association of immigrant and native population and local air quality across all US counties. Their main funding is that the autocorrelation of air quality requires use of spatial analysis. Their statistical analysis suggest that native population is associated with worse air quality and immigrant population is associated with better quality air. They dispute the studies of Cramer, (1998); Price and Feldmeyer (2012) and Squalli (2009) showing its limitation in sample size and lack of consideration of space dependence, although they provide evidence on the relationship population- air quality. Ma and Hoffmann (2018) conclude suggesting that the existing studies about immigration associated with $\mathrm{CO} 2$ and air quality are limited in number, methodology, and generalization. They conclude that immigrants overall do not reproduce consumer American behavior.

The study of Angus and Butler (2011) about population size, claims that the arguments focus on population growth, specifically on immigration denied the real causes of environmental destruction. For example, variables such as poverty, food shortage, and resources use or over 
exploitation. Therefore, they argue that focusing on immigration population flows avoids the corporation's behavior and other big players impacts, at the state and non-state level, that produce massive environmental damages. Social issues and environmental crisis are not simple numbers. All population growth arguments separate growth from the historical, social, and economic context, it is simplistic. Therefore, an appropriate climate change justice recognizes the responsibility of the Global North in the environmental crisis and the growing of climate refugees that increase immigration flows.

Neumayer $(2005,2006)$ introduce an ethical and theoretical response to the environmental restrictionism. He argues that keeping immigrants out does not solve environmental problems, neither it addresses the reasons for immigration. Globalization should be a promise of sustainable development in the planet; instead, the developing countries need to address simultaneously causes of civil war and sustainable development. Therefore, there is a doble standard for immigration allowing educated and skill people to immigrate and not addressing economic hardship, discrimination, and political oppression that are the determinant causes of asylum seeking and immigration. The environmental control of population needs to be addressed for resources consumption recognizing the political bias and ethical concerns about human rights.

Finally, studies focused on the contradiction of the American environmental movement on supporting the environment argument identified that: in one hand, this argument recognize immigration and environmental degradation driven by transnational political structures, and in the other hand, the authors also appeal to the national social contract to consider ethical obligations excluding those that are not citizens. For example, Hultgren (2014) point out that the environmental restrictionist discourse attempt to protect the nature by building a wall when it is ineffective and unethical and denies the economic and political context of the North American Free Trade, the impacts of the policies of the International Monetary Fund, and the measures of World Bank on Mexico. Then, the environmental argument against immigration is tangle with specific ideas of political community, governance, and political economy that reinforce social exclusionary policies.

\section{Conclusion}

The environmental argument against Latinx immigration (restictionism) is a continuation of race biases ideology that looks eager for theoretical and empirical evidence to provide foundation on an argument that is ethically, and politically incorrect. The origins of the US environmental movement converged in the early twentieth century in a time where eugenics and nativism continued social Darwinism and new versions of Malthusianism. The ideological movement called environmental restrictionism after the 1970 s created three broad discourses: social nativism, eco- 
nativism, and eco-communitarianism. According to Neumayer $(2005,2006)$, social nativism is anthropocentric construction of nature to justify exclusion of the other. For example, a sacred symbol of God's truth or a scientific truth rooted in Darwinism, or a political truth that aligns with a minimal State. The eco-nativism emphasized the importance of national wilderness as a root of national heritage. Therefore, it supports a demographic projection to sustain the idea that overpopulation is the cause of environmental degradation, this is why it is a reformulation of Neo-Malthusian. The latest version of the environmental restrictionism is the eco-communitarianism, principal representants are part of the Sierra Club restrictionist advocates. They use the linkage of immigration and environment deterioration blaming neoliberal economic policies. This third wave of restrictionism use the same discourse with the nuance including greens and liberals.

The core problem of the environmental argument against immigration is that it lacks generalizable studies and objective data to support the main claim that connects immigration with environmental degradation, immigration it is not the only cause of population growth. The main ethical flow is that denies strong evidence and arguments that linkage environmental degradation with industrialization levels, economic development, and consumption levels of the US citizens. The environmental argument instead proposed a smooth translation of a new version of racial biases against Latinx immigration, the studies are focus on population that exclusively came from the south border and does not compare immigration to the US from other continents. Also, as described in the reactions of the literature, the environmental argument has a theoretical root that is connected with sovereignty, nativist, social Darwinism, Malthusianism, and eugenics thinking. The real political tactic that is hidden in this argument is to find a way of justified the privilege of white US population, in terms of consumption and levels of contamination. The versions of the environmental argument analysis in this paper shows how identity and speeches that perpetuated stereotypes (such as immigrants are the main cause of environmental degradation) trigger belonging mechanism. Therefore, the environmental argument makes easier to identify a national (or tribal) boundary far from what is a human being, or respect for universal human rights. Those arguments have the power to influence the politics of race and justify exclusionary immigration polices currently weaponizing environmental protection. 


\section{References}

Angus, I., \& Butler, S. (2011). Too many people?: Population, immigration, and the environmental crisis. Haymarket Books.

Beck, R. H., \& Kolankiewicz, L. J. (2000). The environmental movement's retreat from advocating US population stabilization (1970-1998): A first draft of history. Journal of Policy History, 12(1), 123-156.

Beck, R. H., Kolankiewicz, L. J., \& Camarota, S. A. (2003). Outsmarting smart growth: Population growth, immigration, and the problem of sprawl. Center for Immigration Studies.

Beltrán, C. (2020). Cruelty as Citizenship: How Migrant Suffering Sustains White Democracy. U of Minnesota Press.

Bouvier, L. (1998). The Impact of Immigration on United States' Population Size: 19502050. Washington, DC: Negative Population Growth.

Cafaro, P., \& Staples III, W. (2009). The Environmental Argument for Reducing Immigration into the United States. Environmental Ethics, 31, 5-30. https://doi.org/10.5840/enviroethics20093113

Eckersley, R. (2006). The State as Gatekeeper: A Reply. Politics and Ethics Review, 2(2), 127-138. https://doi.org/10.1177/1743453X0600200205

Hultgren, J. (2012). Natural Exceptions to Green Sovereignty? American Environmentalism and the "Immigration Problem." Alternatives: Global, Local, Political, 37(4), 300-316.

Hultgren, J. (2014). The "Nature" of American Immigration Restrictionism. New Political Science, 36(1), 52-75. https://doi.org/10.1080/07393148.2013.864899 
Kendall, B. (2016, June 3). Trump Says Judge's Mexican Heritage Presents 'Absolute Conflict.' Wall Street Journal. https://www.wsj.com/articles/donald-trump-keeps-up-attacks-onjudge-gonzalo-curiel-1464911442

King, L. (2008). Ideology, Strategy and Conflict in a Social Movement Organization: The Sierra Club Immigration Wars. Mobilization: An International Quarterly, 13(1), 45-61. https://doi.org/10.17813/maiq.13.1.c7pv26280665g90g

Kolankiewicz and Camarota-Immigration to the United States and World-Wide G.pdf. (n.d.). Retrieved April 26, 2021, from https://cis.org/sites/cis.org/files/articles/2008/back1008.pdf

Lashof, D. A., \& Hawkins, D. (n.d.). An Action Plan to Reduce U.S. Global Warming Pollution. 3.

Lutz, W., Sanderson, W., \& Scherbov, S. (2001). The End of World Population Growth. Nature, 412, 543-545. https://doi.org/10.1038/35087589

Ma, G., \& Hofmann, E. T. (2019). Immigration and environment in the U.S.: A spatial study of air quality. The Social Science Journal, 56(1), 94-106. https://doi.org/10.1016/i.soscij.2018.08.007

McKee, J., Chambers, E., \& Guseman, J. (2013). Human Population Density and Growth Validated as Extinction Threats to Mammal and Bird Species. Human Ecology, 41(5), 773-778.

Mudde, C. (2017). The Far Right in America. Routledge.

Neumayer, E. (2005). Bogus Refugees? The Determinants of Asylum Migration to Western Europe. International Studies Quarterly, 49(3), 389-409. https://doi.org/10.1111/j.1468$\underline{2478.2005 .00370 . x}$

Neumayer, E. (2006). The environment: One more reason to keep immigrants out? ECOLOGICAL ECONOMICS, 4. 
Neumayer-2006-The environment One more reason to keep immigrant.pdf. (n.d.).

Nevins, J., \& Nevins, A. (2002). Operation Gatekeeper: The Rise of the "illegal Alien" and the Making of the U.S.-Mexico Boundary. Psychology Press.

Pacala, S., \& Socolow, R. (2004). Stabilization Wedges: Solving the Climate Problem for the Next 50 Years with Current Technologies. Science, 305(5686), 968-972. https://doi.org/10.1126/science.1100103

Rust, N., \& Kehoe, L. (2018). A Call for Conservation Scientists to Empirically Study the Effects of Human Population Policies on Biodiversity Loss [Preprint]. SocArXiv. https://doi.org/10.31235/osf.io/ny5ge

Smith, M. (2011). Against Ecological Sovereignty: Ethics, Biopolitics, and Saving the Natural World. U of Minnesota Press.

Wood, A. L. (2011). Lynching and Spectacle: Witnessing Racial Violence in America, 1890-1940. Univ of North Carolina Press. 